УДК 378:347.78

DOI: 10.37026/2520-6427-2020-103-3-21-29
Олександр КУЛАКОВСЬКИЙ,

аспірант кафедри креативної педагогіки та інтелектуальної власності

Української інженерно-педагогічної академії, м. Харків

\title{
КОМПЕТЕНТНІСНА МОДЕЛЬ ВИПУСКНИКА ПЕДАГОГІЧНОГО ЗАКЛАДУ ВИЩОЇ ОСВІТИ У СФЕРІ ІНТЕЛЕКТУАЛЬНОЇ ВЛАСНОСТІ
}

У статті представлено компетентнісну модель випускника педагогічного закладу вищої освіти у сфері охорони та захисту прав інтелектуальної власності, щзо посідає ключове місие як у процесі розробки, так $і$ впровадження у закладі освіти технології формування певних компетентностей, зокрема й щзодо охорони і захисту прав інтелектуальної власності. Здійснено класифікацію професійної діяльності випускників педагогічних закладів вищої освіти на педагогічну та управлінську діяльність. Залежно від різних критеріїв (виду діяльності, спеціальності педагога, напряму діяльності) проведено класифікаиію основних видів діяльності. Розглянуто особливості професійної діяльності випускника педагогічного закладу вищої освіти, законодавчо обгрунтовано його функиіональні обов'язки у проиесі здійснення педагогічної та управлінської діяльності. Розглянуто правовідносини, учасниками яких є педагогічні прачівники, їхні функиії, компетениії, повноваження. На підставі иьього та на основі блочного принципу побудови компетентнісної моделі розроблено компетентнісну модель випускника педагогічного закладу вищої освіти. Запропонована компетентнісна модель випускника педагогічного закладу вищчої освіти у сфері охорони та захисту прав інтелектуальної власності охоплює здійснення ним педагогічної діяльності в закладах освіти, методичних иееттрах, иентрах професійного розвитку педагогічних працівників (професійно-діяльнісний (педагогічний) блок, інновачійно-економічний блок), а також управлінську діяльність, яка здійснюється на керівних посадах в закладах освіти, наукових установах, методичних центрах, центрах професійного розвитку педагогічних працівників (інновачійно-управлінський блок).

Ключові слова: компетентнісна модель, компетентність, випускник педагогічного закладу вищоі освіти, охорона та захист інтелектуальної власності, педагогічна діяльність.

В статье представлена компетентностная модель выпускника педагогического учреждения высшего образования в сфере охраны и зашиты прав интеллектуальной собственности, занимающая цеентральное место как в прочессе разработки, таки внедрения в учебном заведении технологии формирования определенных компетенций, в частности по охране и замите прав интеллектуальной собственности. Проведена классификация профессиональной деятельности выпускников педагогических заведений высшего образования на педагогическую и управленческую деятельность. В зависимости от различных критериев (вида деятельности, специиальности педагога, направления деятельности, проведена классификация основных видов деятельности) рассмотрень особенности профессиональной деятельности выпускника педагогического учреждения высшего образования, законодательно обосновано его функииональные обязанности в проиессе осуществления педагогической и управленческой деятельности. Рассмотрень правоотношения, участниками которых являются педагогические работники, их функции, компетенции, полномочия. На основании этого, а также на основе блочного приниипа построения компетентностной модели, разработана компетентностная модель выпускника педагогического учреждения высшего образования. Предложенная компетентностная модель выпускника педагогического учреждения высшего образования в сфере охраны и зашиты прав интеллектуальной собственности охватывает совершение им педагогической деятельности в учреждениях образования, методических иентрах, иентрах профессионального развития педагогических работников (профессионально-деятельностный (педагогический) блок, инновационно-экономический блок), а также управленческую деятельность, осуществляемую на руководящих должностях в учебных заведениях, научных учреждениях, методчческих иентрах, иентрах профессионального развития педагогических работников (инновационно-управленческий блок).

Ключевые слова: компетентностная модель, компетентность, выпускник педагогического учреждения высшего образования, охрана и защита интеллектуальной собственности, педагогическая деятельность.

Theoretical and methodological substantiation is provided in this article. A competency model of a graduate of a pedagogical institution of higher education in the field of protection and preservation of intellectual 
property rights, which occupies a central place both in the development and implementation of technologies for the formation of certain competencies in an educational institution, in particular for protection and preservation of intellectual property rights is developed. The professional activity of graduates of pedagogical institutions of higher education is classified into pedagogical and managerial. Depending on various criteria, in particular, the type of activity, the specialty of the teacher, the direction of activity, the classification of the main types of activity is carried out. The features of the professional activity of graduates of pedagogical institutions of higher education are considered. His functional duties, in the process of carrying out pedagogical and administrative activities, are legally substantiated. The legal relations in which teaching staff participate, their functions, competencies and powers are examined.. Based on this and on the basis of the block principle of building a competence model, a competence model of a graduate of a pedagogical institution of higher education is developed. The proposed competence model of graduates of a pedagogical institutions of higher education in the field of protection and preservation of intellectual property rights covers his pedagogical activities in educational institutions, methodological centers, centers for the professional development of teachers (professional activity (pedagogical) block, innovation and economic block), as well as managerial activities carried out in managerial positions in educational institutions, scientific institutions, methodological centers, centers for the teacher's professional development (innovation and management block).

Key words: competence model, competence, graduate of a pedagogical institution of higher education, protection and preservation of intellectual property, pedagogical activity.

Постановка проблеми. Якість надання освітніх послуг - основа економічного розвитку держави. Важливою складовою цього процесу $є$ процедура формування професійних компетентностей фахівця під час навчання у закладі вищої освіти (далі - 3BO). У контексті проблематики, що розглядається у нашому дослідженні, наголосимо, що діяльність майбутнього педагога безпосередньо пов'язана 3 використанням інноваційних технологій, їх створенням та запровадженням в освітній процес. 3 огляду на це, ключовим вважаємо формування компетентності у сфері охорони та захисту прав інтелектуальної власності. Означена компетентність фактично є однією 3 умов інноваційного розвитку на сучасному етапі розвитку освіти. Формування компетентності у сфері охорони та захисту прав інтелектуальної власності - складна процедура, що потребує певного теоретико-методологічного й технологічного обгрунтування, зокрема наповнення структурних компонентів цієі компетентності, визначення їі місця та ролі у професійній підготовці майбутніх педагогів

Аналіз наукових досліджень і публікацій. До розгляду загальних питань компетентнісного підходу зверталися чимало вчених, як-от: В. Лунячек [11] (професійна підготовка студентів (слухачів) в умовах 3ВО iз позицій компетентнісного підходу), Л. Гуцан [2] (особливості впровадження компетентнісного підходу в закладах загальної середньої освіти); О. Часнікова [19] (сутність, функції та особливості реалізації компентентнісного підходу); В. Ягупов і В. Свистун [21] (вплив компетентнісного підходу на підготовку фахівців у системі вищої освіти); В. Ковальчук [8] (професійна компетентність вчителя); О. Іваницький [7] (формування інтегральної компетентності майбутнього вчителя фізики) та ін.

Трансформація підходів щодо надання освітніх послуг стала підгрунтям для дослідження та розробки підходів формування окремих спеціальних компетентностей за напрямами діяльності майбутніх фахівців. У зв'язку з цим показовими є роботи А. Куруч (здійснено аналіз педагогічної компетентності курсантів Національної академії Національної гвардії України); О. Міршук (схарактеризовано особливості формування педагогічної компетентності магістрів непедагогічних спеціальностей); Л. Половенко [13] (проаналізовано управлінську компетентність фахівців економічного профілю); О. Мондич (окреслено формування компетентності майбутніх учителів початкової школи з анатомії та фізіології людини); С. Яблоков (описано формування загальнокультурної компетентності майбутніх учителів іноземної мови); I. Маркевич (розглянуто формування інформаційної компетентності майбутніх учителів географії у процесі професійної підготовки) та ін.

Викладене вище слугує підтвердженням актуальності та важливості науково-методичного обгрунтування формування компетентностей фахівців, які є складовою їхньої інтегральної компетентності. Стратегічним напрямом реформування вітчизняної освіти, як зазначає Г. Зікій, є впровадження компетентнісного підходу, який підкреслює роль досвіду, здатності практично реалізовувати знання, орієнтуватися у нестандартних ситуаціях та успішно вирішувати професійні завдання [6].

Для побудови компетентнісної моделі випускників педагогічних закладів вищої освіти необхідно також звернутися до поняття «модель», зокрема окреслити сутність процесу педагогічного моделювання. Використання моделювання в педагогіці дає можливість детально проаналізувати та оцінити основні етапи навчального процесу, його елементи та поведінку суб'єктів. Крім того, воно спрямоване на побудову «ідеальної моделі», завдання якої - оптимізувати процес навчання, підвищити його результативність [20, с. 39]. На думку С. Архангельского, моделювання у педагогічних дослідженнях обумовлено складністю освітнього процесу, постійною зміною умов, неможливістю спостерігати однакові процеси двічі [1]. Я. Сікора, описуючи модель формування професійної компетентності майбутнього вчителя інформатики, розглядає іiі як теоретичне обгрунтування та сутнісне тлумачення структурних компонентів, що розкриває особливості змісту та структури, послідовність, взаємозв'язок усіх складових означеного процесу $[18$, с. 10]. Зі свого боку Н. Волкова зауважує, що стратегічна ціль педагогічного моделювання полягає у підготовці фахівця відповідно до ідеалів професійності [2, с. 144].

Таким чином, можемо зробити висновок, що значення педагогічного моделювання полягає у можливості візуалізації та теоретичному обгрунтуванні необхідних майбутньому фахівцеві знань, умінь, навичок та особистих якостей 3 урахуванням потреб ринку праці, що є основою для розробки навчальних планів підготовки фахівців відповідної спеціальності. Розробка компетентнісних моделей майбутніх педагогів має особливе практичне значення, оскільки їхня професійна діяльність передусім пов'язана з формуванням компетентностей в учнів (студентів) закладів 
освіти відповідного рівня (залежно від спеціальності майбутнього педагога), із веденням наукової діяльності та забезпеченням функціонування закладу освіти як автономного суб'єкта господарювання.

Винятково важливе місце займає обгрунтування компетентнісної моделі випускника педагогічного закладу вищої освіти як майбутнього фахівця, який у своїй професійній діяльності забезпечуватиме реалізацію освітньої політики держави у процесі формування компетентностей учасників освітнього процесу.

П. Кравчук відзначає, що «особливості сучасного етапу суспільного розвитку вимагають від сучасного студента наукового світогляду, творчої гнучкості, соціальної відповідальності, суспільної активності» [9]. Модель спеціаліста, з точки зору В. Лозовецької, повинна відображати об'єктивні закономірності розвитку галузі професійної діяльності, місця і ролі спеціаліста в ній, перелік посад і професійних функцій, до виконання яких він готується у процесі навчання в системі професійної підготовки, основні вимоги до змісту знань та вмінь, необхідних для успішного виконання професійних обов'язків, а також для подальшого розвитку професійно важливих і особистісних якостей та ін. [5, с. 516].

Компетентнісні моделі є основою процесу формування спеціаліста у процесі його підготовки в закладі освіти, перепідготовки у процесі підвищення кваліфікації, а також можуть бути основою для ефективного управління ресурсами в організації, що зумовлено положеннями Державного стандарту України ISO 9001:2001 [4].

Відповідно до П. 6.2 зазначеного нормативного документа персонал, залучений до робіт, що впливають на якість продукції, повинен бути компетентним, тобто мати належні освіту, професійну підготовку, кваліфікацію та досвід. Організація повинна: а) визначити необхідний рівень компетентності для персоналу, залученого до робіт, що впливають на якість продукції (при цьому поняття продукція відповідно до положень зазначеного стандарту може також означати послугу); б) організовувати підготовку або вживати інших заходів для задоволення цих потреб; в) оцінювати ефективність вжитих заходів; г) забезпечувати обізнаність персоналу щодо доцільності та важливості своєї діяльності і щодо свого внеску в досягнення цілей у сфері якості; д) реєструвати дані стосовно освіти, професійної підготовки, кваліфікації та досвіду [4, с. 5-6].

Таким чином, компетентнісні моделі випускників відповідних спеціальностей повинні узгоджуватися iз компетентнісними моделями, що розробляються суб'єктами господарювання для працівників відповідних професій, які залучені до виконання обов'язків на підприємстві.

Варто зауважити, що науково-теоретичні розробки компетентнісних моделей випускників педагогічних закладів вищої освіти перебувають на початковому етапі свого розвитку, а отже, потребують удосконалення. Підготовка майбутніх спеціалістів повинна враховувати особливості майбутньої професійної діяльності фахівця певного напряму підготовки. Компетентнісна модель посідає центральне місце як у процесі розробки, так і впровадження у закладі освіти технології формування певних компетентностей, зокрема й щодо охорони і захисту прав інтелектуальної власності.
Метою статті $є$ теоретико-методологічне обгрунтування та розроблення компетентнісної моделі випускника педагогічного закладу вищої освіти у сфері охорони та захисту прав інтелектуальної власності.

Виклад основного матеріалу. Основною професійною діяльністю випускника педагогічного закладу вищої освіти є педагогічна діяльність. Відповідно до п. 21 ч. 1 ст. 1 Закону України «Про освіту» [16] педагогічна діяльність визначається як інтелектуальна, творча діяльність педагогічного (науково-педагогічного) працівника або самозайнятої особи у формальній та/або неформальній освіті, спрямована на навчання, виховання та розвиток особистості, іiі загальнокультурних, громадянських та/або професійних компетентностей. Разом із тим певний відсоток випускників педагогічних закладів вищої освіти в результаті професійної кар'єри можуть обіймати керівні посади в закладах освіти. Управлінська діяльність керівних працівників закладів передбачає трансформацію компетентності у сфері охорони та захисту прав інтелектуальної власності, здобуту у процесі їх навчання з урахуванням виконання такими працівниками управлінських функцій.

Таким чином, професійну діяльність випускників педагогічних закладів вищої освіти можна поділити на педагогічну діяльність та управлінську. Зазначені види діяльності можуть здійснюватися в: 1) закладах освіти; 2) органах управління освітою; 3) центрах професійного розвитку, методичних центрах (кабінетах), інших науково-методичних установах.

Види педагогічної діяльності як основного виду діяльності випускника педагогічного закладу вищої освіти можна визначити відповідно до таких класифікаційних критеріїв:

1) залежно від виду діяльності: а) педагогічна діяльність у межах педагогічного навантаження; б) інші види педагогічної діяльності;

2) залежно від спеиіальності педагога: а) педагогічна діяльність у дошкільній освіті; б) педагогічна діяльність у початковій освіті; в) педагогічна діяльність у загальній середній освіті; г) педагогічна діяльність у професійній освіті; д) педагогічна діяльність у спеціалізованій освіті;

3) залежно від напряму діяльності: а) практична педагогічна діяльність; б) наукова (в межах підготовки наукових працівників в аспірантурі, робота в наукових установах тощо); в) науково-практична діяльність (в межах інноваційних інфраструктур кластерів, технопарків, технополісів тощо).

Крім того, реалізація компетентності у сфері охорони та захисту прав інтелектуальної власності майбутніх педагогічних працівників здійснюється не тільки на стадії їхньої професійної діяльності, а й у процесі навчання. Студенти педагогічних закладів вищої освіти як учасники освітнього процесу можуть бути учасниками студентської наукової діяльності, академічної мобільності (як міжнародної, так і внутрішньодержавної), а також виконавцями освітньо-наукових проєктів, господарських договорів, що укладаються закладами вищої освіти. У зв'язку з цим вони здійснюють реалізацію, охорону та захист прав інтелектуальної власності, повинні дотримуватися правил академічної доброчесності як умови якісної освітньої діяльності. Їхня подальша педагогічна діяльність (освітня, наукова, інноваційна) здійснюватиметься також у межах закладу освіти, проте відрізнятиметься функціональними повноваженнями виконавців. 
Саме тому важливо застосовувати комплексний підхід до формування компетентнісної моделі випускників педагогічних закладів вищої освіти у сфері охорони та захисту прав інтелектуальної власності, що $\epsilon$ основою не тільки ефективної реалізації соціального замовлення на підготовку професіоналів, але й забезпечення інноваційного розвитку держави в цілому.

У процесі проведення дослідження нами було розроблено компетентнісну модель випускника педагогічного закладу вищої освіти у сфері охорони та захисту прав інтелектуальної власності на основі блочного принципу побудови компетентнісної моделі, наведеної у роботі В. Лунячека та Н. Рубан [12] щодо компетентнісної моделі працівника загальної середньої освіти, яка складається $з$ таких блоків: 1) інноваційно-освітній, 2) професійно-діяльнісний, 3) інноваційно-економічний, 4) інноваційно-управлінський.

Розглядаючи професійну діяльність випускників педагогічних закладів вищої освіти, насамперед розглянемо функціональні обов'язки здійснення педагогічної діяльності.

Особливістю, яка відрізняє педагогічну діяльність від інших видів діяльності є те, що в процесі їі здійснення педагог повинен формувати у здобувачів освіти (як початкової, так і загальної середньої та професійно-технічної, а згодом - і вищої) відповідні компетентності. У зв'язку з цим, описуючи професійну діяльність педагогів, зокрема й ту, що пов'язана 3 діяльністю у сфері охорони та захисту інтелектуальної власності, необхідно проаналізувати положення державних стандартів початкової та загальної середньої освіти з метою визначення компетентностей, які повинні отримати здобувачі відповідного рівня освіти.

Однією із ключових компетентностей у сфері інтелектуальної власності відповідно до Державного стандарту початкової освіти, затвердженого Постановою КМУ від 21.02.2018 № 87 [14], є інноваційність.

Державний стандарт базової середньої освіти наразі не затверджено. На громадське обговорення запропоновано проєкт такого стандарту, згідно з яким одним із ціннісних орієнтирів, на якому грунтується базова середня освіта, $є$ утвердження людської гідності та доброчесності, зокрема академічної, через виховання чесності, відваги, наполегливості, милосердя, доброти, справедливості, поваги до прав людини (важливими правами людини є особисті немайнові та майнові права на результати своєї інтелектуальної (творчої) діяльності).

Одним зі способів забезпечення реалізації означених прав $\epsilon$ формування компетентності у сфері охорони та захисту прав інтелектуальної власності у випускників педагогічних закладів вищої освіти, які в процесі виконання професійних завдань забезпечуватимуть формування вказаних компетентностей в учасників освітнього процесу.

Іншим аспектом діяльності майбутнього педагога варто визначити необхідність дотримання ним вимог нормативно-правових актів щодо функціонування системи освіти та забезпечення якості надання освітніх послуг. У зв'язку з цим необхідно звернути увагу на статтю 6 Закону України «Про освіту» [16], яка визначає основні засади державної освітньої політки, серед положень якої варто виокремити такі принципи, як: 1) забезпечення якості освіти та якості освітньої діяльності; 2) академічна доброчесність; 3) науковий характер освіти; 4) інтеграція в міжнародний освітній та науковий простір; 5) формування поваги до прав і свобод людини; 6) державно-приватне партнерство.
Однією із новел законодавства про освіту є академічна доброчесність. Дотримання академічної доброчесності $€$ вагомим компонентом внутрішнього забезпечення якості освіти, дотримання якої відповідно до ст. 42 Закону України «Про освіту» є важливою характеристикою надання якісних освітніх послуг, інтеграції в міжнародний освітній та науковий простір та забезпечення наукового характеру освіти. Фактично академічна доброчесність є похідною дотримання прав інтелектуальної власності, а тому однією зі складових компетентнісної моделі випускника педагогічного закладу вищої освіти у сфері охорони та захисту прав інтелектуальної власності необхідно визначити дотримання правил академічної доброчесності. Це дозволить майбутнім педагогам застосовувати відповідну компетентність у процесі здійснення педагогічної діяльності для формування знань, умінь та навичок дотримання правил академічної доброчесності в учнів закладів загальної середньої освіти (як із боку педагогічних працівників так і здобувачів освіти).

Одним із напрямів державно-приватного партнерства як принципу освітньої діяльності є утворення та/або спільне фінансування й експлуатація інноваційних підприємств (інноваційний центр, технопарк, технополіс, інноваційний бізнес-інкубатор тощо) на базі існуючих закладів освіти. У межах зазначеної діяльності випускники педагогічних закладів вищої освіти повинні мати компетентності, що пов'язані 3 можливістю впровадження інновацій у професійну практичну діяльність, знати принципи, порядок та особливості комерціалізації об'єктів інтелектуальної власності, розуміти порядок та принципи діяльності інноваційних інфраструктур, що також входить до складу компетентності у сфері охорони та захисту прав інтелектуальної власності як важливої складової професійної педагогічної діяльності.

Відповідно до ст. 54 Закону України «Про освіту» педагогічні, науково-педагогічні, наукові працівники мають право на розроблення та впровадження авторських навчальних програм, проєктів, освітніх методик (насамперед методик компетентнісного навчання) i технологій, методів і засобів, що також є об'єктами інтелектуальної власності, впровадження яких потребує знань у сфері охорони та захисту прав інтелектуальної власності. Ще у 2007 році Постановою Верховної Ради України було схвалено Рекомендації парламентських слухань «Захист прав інтелектуальної власності в Україні: проблеми законодавчого забезпечення та правозастосування» [17], в яких однією із проблем було визначено те, що непоодинокими $\epsilon$ випадки, коли через низьку правову та економічну культуру суб' єкти науково-технічної та економічної діяльності добровільно відмовляються від використання існуючих механізмів захисту своїх прав та інтересів як власники інтелектуальних здобутків.

У межах педагогічної діяльності варто також відзначити діяльність у центрах професійного розвитку педагогічних працівників. Такі центри на сьогодні перебувають на етапі створення та $є$ новелою законодавства про освіту. Наразі розроблено проєкт Положення про діяльність центру професійного розвитку педагогічних працівників [15], який винесено на громадське обговорення.

Як було зазначено вище, випускник педагогічного закладу вищої освіти у процесі кар'єрного зростання може також займати керівні посади в закладах освіти, органах управління освітою, методичних центрах, центрах професійного розвитку педагогічних працівників. 
Керівні посади передбачають здійснення управлінської діяльності, яка передусім полягає в забезпеченні формування освітнього простору, в межах якого в учасників освітнього процесу формується нетерпимість до порушення прав інтелектуальної власності, забезпеченні високої якості надання освітніх послуг, створенні передумов до інноваційної педагогічної діяльності, а також здійсненні контролю за дотриманням прав інтелектуальної власності здобувачами освіти та педагогами. Серед повноважень керівника закладу освіти, в межах предмета нашого дослідження, варто виокремити питання функціонування внутрішньої системи забезпечення якості освіти. Зважаючи на це, керівник розробляє та реалізовує стратегію розвитку закладу освіти, приймає рішення про участь даного закладу в інноваційних проєктах, про укладення договорів державно-приватного партнерства, про забезпечення захисту прав інтелектуальної власності в закладах освіти, про розробку та впровадження об'єктів інтелектуальної власності в комерційний обіг та їх застосування у межах навчання.
Формування компетентності випускників педагогічних закладів вищої освіти у сфері охорони та захисту прав інтелектуальної власності забезпечить можливість випускника педагогічного закладу вищої освіти не просто створювати об'єкти інтелектуальної власності, а й забезпечувати їх ефективний захист, упровадження в комерційний обіг, забезпечення дотримання своїх прав 3 боку інших осіб та забезпечення управління об'єктами інтелектуальної власності, самостійно створеними в процесі інтелектуальної діяльності, а також у процесі керівництва інтелектуальною діяльністю, що є показником спроможності до ефективного виконання професійних завдань. Вказане $є$ основою для формування цілей підготовки випускника педагогічної спеціальності.

Зважаючи на викладене вище, пропонуємо розроблену нами компетентнісну модель випускника педагогічного закладу вищої освіти (див. табл.).

Табличя

\section{Компетентнісна модель випускника педагогічного закладу вищої освіти} у сфері охорони та захисту прав інтелектуальної власності

\begin{tabular}{|c|c|c|c|c|}
\hline $\begin{array}{c}\text { Назва } \\
\text { компетентності }\end{array}$ & Знання & Уміння & Навички & $\begin{array}{c}\text { Професійно- } \\
\text { важливі якості }\end{array}$ \\
\hline \multicolumn{5}{|c|}{ Інноваційно-освітній блок } \\
\hline $\begin{array}{c}\text { Здатність } \\
\text { забезпечувати } \\
\text { дотримання } \\
\text { академічної } \\
\text { доброчесності }\end{array}$ & \begin{tabular}{|c|} 
знати правила та вимоги \\
дотримання академічної \\
доброчесності, визначені \\
ст. 42 Закону України \\
«Про освіту», статтями 58 \\
і 63 «Про вищу освіту», \\
локальними нормативно- \\
правовими актами \\
закладів освіти
\end{tabular} & \begin{tabular}{|c|} 
уміти реалізовувати \\
права і виконувати \\
обов'язки 3 \\
дотриманням правил \\
академічної \\
доброчесності
\end{tabular} & \begin{tabular}{|c|} 
посилатися на дже- \\
рела інформації у разі \\
використання ідей та \\
розробок інших авто- \\
рів, надавати досто- \\
вірну інформацію про \\
власні наукові здо- \\
бутки, дотримуватися \\
правил академічної \\
доброчесності та по- \\
ваги до прав інтелек- \\
туальної власності
\end{tabular} & $\begin{array}{c}\text { доброчесність, } \\
\text { чесність, } \\
\text { справедливість, } \\
\text { культура, висока } \\
\text { моральність }\end{array}$ \\
\hline $\begin{array}{c}\text { Здатність бути } \\
\text { суб’єктом } \\
\text { правовідносин } \\
\text { у сфері охорони } \\
\text { та захисту прав } \\
\text { інтелектуальної } \\
\text { власності }\end{array}$ & $\begin{array}{c}\text { знати правові основи реа- } \\
\text { лізації прав інтелектуаль- } \\
\text { ної власності, визначені } \\
\text { книгою } 4 \text { Цивільного ко- } \\
\text { дексу України, главою } 16 \\
\text { Господарського кодексу, } \\
\text { а також Законами України } \\
\text { «Про авторське право і } \\
\text { суміжні права», «Про } \\
\text { охорону прав на винаходи } \\
\text { і корисні моделі» та } \\
\text { іншими законодавчими } \\
\text { актами, що регулюють } \\
\text { діяльність у сфері } \\
\text { інтелектуальної власності }\end{array}$ & $\begin{array}{c}\text { реалізовувати } \\
\text { майнові та особисті } \\
\text { немайнові права на } \\
\text { власні освітньо- } \\
\text { наукові проєкти, } \\
\text { забезпечувати їх } \\
\text { охорону і захист як } \\
\text { об'єктів } \\
\text { інтелектуальної } \\
\text { власності }\end{array}$ & $\begin{array}{c}\text { визначати вид об’єкта } \\
\text { інтелектуальної } \\
\text { власності щодо } \\
\text { власних інноваційних } \\
\text { розробок, формувати } \\
\text { пакет документів на } \\
\text { отримання охоронних } \\
\text { документів на } \\
\text { визначені об'єкти та } \\
\text { укладати договори } \\
\text { щодо передачі прав на } \\
\text { них }\end{array}$ & $\begin{array}{c}\text { юридична } \\
\text { грамотність, } \\
\text { аналітичне та } \\
\text { інноваційне } \\
\text { мислення }\end{array}$ \\
\hline \multicolumn{5}{|c|}{ Професійно-діяльнісний блок (педагогічний) } \\
\hline \begin{tabular}{|c|} 
Здатність \\
до розробки \\
інноваційних \\
проєктів у межах \\
педагогічної \\
діяльності
\end{tabular} & \begin{tabular}{|c|} 
знати сучасні інноваційні \\
освітні технології, \\
принципи та способи їх \\
застосування, створення \\
на їх основі власних \\
педагогічних розробок
\end{tabular} & \begin{tabular}{|c|} 
розробляти та впрова- \\
джувати інноваційні \\
способи навчання та \\
викладання, розв’язу- \\
вати нетипові профе- \\
сійні педагогічні \\
завдання \\
\end{tabular} & $\begin{array}{c}\text { упроваджувати } \\
\text { освітні інноваційні } \\
\text { технології в } \\
\text { педагогічній } \\
\text { діяльності }\end{array}$ & $\begin{array}{c}\text { креативне } \\
\text { мислення, } \\
\text { ініціативність, } \\
\text { орієнтація на } \\
\text { ефективність, } \\
\text { цілеспрямова- } \\
\text { ність }\end{array}$ \\
\hline
\end{tabular}


Продовження таблииі

\begin{tabular}{|c|c|c|c|c|}
\hline $\begin{array}{c}\text { Назва } \\
\text { компетентності }\end{array}$ & Знання & Уміння & Навички & $\begin{array}{c}\text { Професійно- } \\
\text { важливі якості }\end{array}$ \\
\hline $\begin{array}{c}\text { Здатність } \\
\text { організовувати } \\
\text { творчу } \\
\text { діяльність } \\
\text { учнів }\end{array}$ & $\begin{array}{c}\text { знати методи наукового } \\
\text { пізнання, засоби і форми } \\
\text { вирішення творчих } \\
\text { завдань }\end{array}$ & $\begin{array}{c}\text { залучати учнів до про- } \\
\text { ведення досліджень, } \\
\text { написання наукових } \\
\text { робіт, участі в олім- } \\
\text { піадах, конкурсах, } \\
\text { турнірах, конкурсах- } \\
\text { захистах Малої ака- } \\
\text { демії наук, визначати } \\
\text { результати їхньої } \\
\text { творчої діяльності як } \\
\text { об'єкти інтелек- } \\
\text { туальної власності }\end{array}$ & $\begin{array}{c}\text { управляти } \\
\text { творчою діяльністю } \\
\text { учнів задля } \\
\text { отримання об'єктів } \\
\text { інтелектуальної } \\
\text { власності }\end{array}$ & $\begin{array}{l}\text { креативність, } \\
\text { ініціативність, } \\
\text { управлінські } \\
\text { якості, творче } \\
\text { мислення }\end{array}$ \\
\hline $\begin{array}{c}\text { Здатність фор- } \\
\text { мувати в учнів } \\
\text { повагу до прав } \\
\text { інтелектуальної } \\
\text { власності та пра- } \\
\text { вил академічної } \\
\text { доброчесності }\end{array}$ & $\begin{array}{c}\text { знати види та ознаки } \\
\text { порушень прав інтелек- } \\
\text { туальної власності й ака- } \\
\text { демічної доброчесності, } \\
\text { методи мотивації щодо } \\
\text { запобігання відповідних } \\
\text { правопорушень }\end{array}$ & $\begin{array}{c}\text { визначати діяння, які } \\
\text { є правопорушеннями } \\
\text { у сфері інтелек- } \\
\text { туальної власності } \\
\text { та види відповідаль- } \\
\text { ності за їх вчинення }\end{array}$ & $\begin{array}{c}\text { організовувати і } \\
\text { проводити превен- } \\
\text { тивні заходи } 3 \text { метою } \\
\text { подолання правового } \\
\text { нігілізму в учнів }\end{array}$ & \begin{tabular}{l|c} 
- & нетерпимість до \\
правопорушень, \\
го
\end{tabular} \\
\hline $\begin{array}{c}\text { Здатність забез- } \\
\text { печити ефек- } \\
\text { тивну охорону } \\
\text { і захист прав } \\
\text { інтелектуальної } \\
\text { власності та } \\
\text { результати твор- } \\
\text { чої діяльності } \\
\text { учасників освіт- } \\
\text { нього процесу }\end{array}$ & $\begin{array}{l}\text { знати основні види та } \\
\text { способи охорони та } \\
\text { захисту прав інтелек- } \\
\text { туальної власності }\end{array}$ & $\begin{array}{c}\text { визначати способи } \\
\text { охорони та захисту } \\
\text { прав інтелектуальної } \\
\text { власності, факти } \\
\text { порушення цих прав, } \\
\text { забезпечувати охоро- } \\
\text { ну доказів приналеж- } \\
\text { ності прав інтелек- } \\
\text { туальної власності та } \\
\text { фактів їх порушенн, } \\
\text { звертатися до суду та } \\
\text { органів державної } \\
\text { влади, які наділені } \\
\text { повноваженнями } \\
\text { щодо вирішення спо- } \\
\text { рів у сфері інтелек- } \\
\text { туальної власності }\end{array}$ & $\begin{array}{c}\text { забезпечувати } \\
\text { належність та } \\
\text { допустимість доказів } \\
\text { порушень прав } \\
\text { інтелектуальної } \\
\text { власності учасників } \\
\text { освітнього процесу, } \\
\text { доводити вчинення } \\
\text { таких порушень }\end{array}$ & \begin{tabular}{c|c} 
& аналітичне \\
мислення, \\
iв \\
наполегливість \\
у, \\
я
\end{tabular} \\
\hline \multicolumn{5}{|c|}{ Інноваційно-економічний блок } \\
\hline $\begin{array}{c}\text { Здатність до } \\
\text { визначення вар- } \\
\text { тості об'єкта } \\
\text { інтелектуальної } \\
\text { власності та його } \\
\text { конкурентоздат- } \\
\text { ності на ринку } \\
\end{array}$ & $\begin{array}{c}\text { знати методи оцінки } \\
\text { вартості об'єктів } \\
\text { інтелектуальної } \\
\text { власності та ознаки } \\
\text { конкурентоздатності }\end{array}$ & $\begin{array}{c}\text { розраховувати } \\
\text { вартість прав на } \\
\text { об'єкт інтелектуаль- } \\
\text { ної власності } \\
3 \text { урахуванням рівня } \\
\text { його конкуренто- } \\
\text { здатності на ринку } \\
\end{array}$ & $\begin{array}{c}\text { проводити оцінку } \\
\text { привабливості ство- } \\
\text { реного об'єкта інте- } \\
\text { лектуальної влас- } \\
\text { ності та визначати } \\
\text { його конкуренто- } \\
\text { здатність } \\
\end{array}$ & $\begin{array}{l}\text { організованість, } \\
\text { аналітичний } \\
\text { склад розуму, } \\
\text { економічне } \\
\text { мислення }\end{array}$ \\
\hline $\begin{array}{c}\text { Здатність до } \\
\text { комерціалізації } \\
\text { об'єктів інтелек- } \\
\text { туальної власнос- } \\
\text { ті, що створені } \\
\text { учасниками освіт- } \\
\text { нього процесу }\end{array}$ & $\begin{array}{c}\text { знати способи та засоби } \\
\text { комерціалізації об'єктів } \\
\text { інтелектуальної власності } \\
\text { та основи інвестиційної } \\
\text { діяльності, види договорів } \\
\text { трансферу технологій }\end{array}$ & \begin{tabular}{|c|} 
визначати спосіб \\
комерціалізації \\
відповідного об'єкта \\
інтелектуальної \\
власності, ство- \\
рений учасниками \\
освітнього процесу
\end{tabular} & $\begin{array}{c}\text { розробляти та } \\
\text { укладати договори, } \\
\text { що опосередко- } \\
\text { вують діяльність у } \\
\text { сфері трансферу } \\
\text { технологій }\end{array}$ & $\begin{array}{c}\text { підприємницька } \\
\text { активність }\end{array}$ \\
\hline \multicolumn{5}{|c|}{ Інноваційно-управлінський блок } \\
\hline $\begin{array}{c}\text { Здатність роз- } \\
\text { повсюджувати } \\
\text { інформацію про } \\
\text { об'єкти інтелек- } \\
\text { туальної влас- } \\
\text { ності закладу } \\
\text { освіти }\end{array}$ & $\begin{array}{c}\text { знати основи марке- } \\
\text { тингової діяльності щодо } \\
\text { просування інноваційних } \\
\text { продуктів на ринку, } \\
\text { сучасні технології } \\
\text { розповсюдження } \\
\text { інформації }\end{array}$ & \begin{tabular}{|c|} 
використовувати \\
сучасні маркетин- \\
гові та інформаційні \\
технології з метою \\
розповсюдження \\
відомостей про \\
об'єкти інтелек- \\
туальної власності \\
\end{tabular} & $\begin{array}{c}\text { просувати } \\
\text { результати } \\
\text { інтелектуальної } \\
\text { (творчої) діяльності } \\
\text { закладу освіти на } \\
\text { ринку за допомогою } \\
\text { інформаційних } \\
\text { технологій } \\
\end{array}$ & $\begin{array}{c}\text { спроможність } \\
\text { використову- } \\
\text { вати 3МІ, } \\
\text { ІТ-технології, } \\
\text { зокрема можливості } \\
\text { соціальних мереж, } \\
\text { для просування } \\
\text { продукту на ринку }\end{array}$ \\
\hline
\end{tabular}


Продовження таблиці

\begin{tabular}{|c|c|c|c|c|}
\hline $\begin{array}{c}\text { Назва } \\
\text { компетентності }\end{array}$ & Знання & Уміння & Навички & $\begin{array}{c}\text { Професійно- } \\
\text { важливі якості }\end{array}$ \\
\hline $\begin{array}{c}\text { Здатність забез- } \\
\text { печувати реалі- } \\
\text { зацію прав і } \\
\text { обов'язків зак- } \\
\text { ладу освіти як } \\
\text { учасника іннова- } \\
\text { ційних та інших } \\
\text { міжгалузевих } \\
\text { кластерів }\end{array}$ & $\begin{array}{c}\text { знати основи } \\
\text { кластерного підходу } \\
\text { щодо забезпечення } \\
\text { інноваційного розвитку } \\
\text { освітньо-наукової } \\
\text { діяльності }\end{array}$ & $\begin{array}{c}\text { реалізовувати } \\
\text { інноваційні проєкти } \\
\text { в межах об’єднання } \\
\text { освіти, науки і } \\
\text { виробництва }\end{array}$ & $\begin{array}{c}\text { упроваджувати } \\
\text { результати } \\
\text { інноваційних } \\
\text { розробок учасників } \\
\text { освітнього процесу } \\
\text { в практичну } \\
\text { діяльність }\end{array}$ & $\begin{array}{c}\text { підприємливість, } \\
\text { економічна } \\
\text { активність, } \\
\text { амбіційність }\end{array}$ \\
\hline
\end{tabular}

Запропонована вище компетентнісна модель випускника педагогічного закладу вищої освіти у сфері охорони та захисту прав інтелектуальної власності охоплює здійснення ним педагогічної діяльності в закладах освіти, методичних центрах, центрах професійного розвитку педагогічних працівників (професійно-діяльнісний (педагогічний) блок, інноваційно-економічний блок), а також управлінську діяльність, яка здійснюється на керівних посадах у закладах освіти, наукових установах, методичних центрах, центрах професійного розвитку педагогічних працівників (інноваційно-управлінський блок).

Інновачійно-освітній блок включає компетентності, необхідні студентам педагогічних закладів вищої освіти ще у процесі навчання. Набувши ці компетентності, випускник педагогічного закладу вищої освіти зможе використовувати їх у майбутній професійній діяльності. При цьому реалізація знань, умінь та навичок, які характеризують компетентності, визначені у цьому блоці, будуть відрізнятися залежно від статусу (студент, працівник) та посади (педагогічний працівник, керівник).

Професійно-діяльнісний (педагогічний) блок є основним, оскільки описує майбутню педагогічну діяльність випускників закладів вищої освіти. Складовими даного блоку є компетентності, що спрямовані на впровадження у власну педагогічну діяльність інноваційних технологій, керівництво творчою діяльністю здобувачів освіти, формування у них компетентності у сфері охорони та захисту прав інтелектуальної власності, здатність до розробки інноваційних проєктів у межах педагогічної діяльності, а також контроль за дотриманням правил академічної доброчесності та прав інтелектуальної власності.

Інновачійно-економічний блок включає компетентності, що забезпечують можливість ефективної реалізації створених об'єктів інтелектуальної власності з метою отримання матеріально-фінансової винагороди та впровадження їх в економічний обіг.

Інноваційно-управлінський блок включає компетентності, які повинні формуватися передусім для здійснення майбутньої управлінської діяльності, проте також $є$ важливими і в межах педагогічної діяльності. На сучасному етапі розвитку економіки заклади освіти є необхідними учасниками різних інноваційних підприємств, їх об'єднань, кластерів. У зв'язку 3 цим здатність забезпечувати реалізацію прав i обов'язків закладу освіти та/або наукової установи як учасників інноваційних й інших міжгалузевих кластерів є важливою складовою компетентнісної моделі як керівників, так і педагогічних працівників закладів освіти, які виступають виконавцями проєктів, що ви- конуються закладом освіти, в якому вони здійснюють свою професійну діяльність.

Таким чином, формування компетентності у сфері інтелектуальної власності у випускників педагогічних закладів вищої освіти є необхідною умовою ефективного виконання ними своїх професійних обов'язків, як у процесі здійснення педагогічної, наукової, управлінської діяльності, так і освітньої. Отримання означених знань, умінь, навичок та професійно-важливих якостей забезпечить сучасні вимоги ринку праці та сприятиме розвитку економіки в цілому.

Висновки. Зважаючи на викладене нами у дослідженні, вважаємо за необхідне зробити такі висновки:

1. Розробка компетентнісної моделі випускника закладу вищої освіти $є$ візуалізацією його повноважень у процесі здійснення майбутньої професійної діяльності. Дослідження функціональних обов'язків фахівців у процесі здійснення ним професійної діяльності $\epsilon$ важливим етапом створення компетентнісних моделей, зокрема надає можливість закладам освіти, що здійснюють підготовку майбутніх педагогів, сформувати у них необхідні знання, вміння, навички та професійно важливі якості для подальшої професійної діяльності випускників відповідно до сучасних вимог ринку праці.

2. Компетентність працівника, зокрема й педагогічного, відповідно до положень Державного стандарту України ISO 9000:2001 включає належні освіту, професійну підготовку, кваліфікацію та досвід. Заклад освіти повинен визначати необхідний рівень компетентності для працівників, які здійснюють педагогічну діяльність. Компетентнісні моделі випускників закладів вищої освіти, зокрема і педагогічних, повинні узгоджуватися з вимогами стейкхолдерів.

3. У процесі щоденної професійної творчої діяльності педагогічний працівник створює об'єкти інтелектуальної власності, використовує їх під час надання освітніх послуг та в процесі діяльності щодо внутрішнього забезпечення якості освіти, керує творчою діяльністю учнів, виконанням ними наукових досліджень, участю в конкурсах, турнірах, захисті наукових робіт тощо. Зважаючи на це, компетентність у сфері охорони та захисту прав інтелектуальної власності $є$ необхідною складовою інтегральної компетентності випускника педагогічного закладу вищої освіти. Залучення студентів, а згодом вчителів до участі в господарській діяльності у ролі суб'єкта, що забезпечує надання освітніх послуг, розробку та впровадження об'єктів інтелектуальної власності в комерційний обіг, також вимагає формування в педагогічних працівників та керівників компетентності у сфері інтелектуальної власності. 
4. Розроблена нами компетентнісна модель випускника педагогічного закладу вищої освіти у сфері охорони та захисту прав інтелектуальної власності враховує всі необхідні компетентності для виконання професійних обов'язків, що пов'язані з інноваційною діяльністю. Насамперед вона спрямована на забезпечення законодавчих вимог, дотримання яких є необхідним у процесі отримання освітніх послуг та здійснення інноваційної педагогічної діяльності. Модель ураховує особливості участі у правовідносинах у сфері інтелектуальної власності студентів педагогічних закладів вищої освіти. Суттєва увага приділена визначенню складових компетентності у сфері охорони та захисту прав інтелектуальної власності, які є необхідними для освітнього процесу студентів педагогічних 3ВО, окреслено принципи трансформації цих компетентностей у майбутню професійну діяльність.

5. Компетентність у сфері охорони та захисту прав інтелектуальної власності визначено як систему знань, умінь, навичок та особистих якостей майбутнього педагогічного працівника як суб'єкта освітньої, наукової, інноваційної діяльності, що може здійснюватися в процесі виконання як педагогічної, так і управлінської діяльності в закладах освіти, органах управління освітою, методичних центрах, наукових установах. Це дозволяє формувати компетентності, необхідні для ефективного ведення професійної діяльності та забезпечувати реалізацію інноваційної політики держави за участю закладів освіти, науки та органів управління у цій сфері.

6. У роботі застосовано блочний принцип побудови компетентнісної моделі випускника педагогічного закладу вищої освіти у сфері охорони та захисту прав інтелектуальної власності, зокрема виділено такі блоки: 1) інноваційно-освітній; 2) професіонально-діяльнісний; 3) інноваційно-економічний; 4) інноваційно-управлінський. Означений підхід дозволяє врахувати державну політику у сфері розвитку освіти, забезпечити інноваційний розвиток економіки держави в цілому, а також сформувати повагу в учасників освітнього процесу до конституційних прав і свобод людини і громадянина, зокрема щодо володіння, користування і розпорядження майновими та особистими немайновими правами інтелектуальної власності.

7. На сучасному етапі розвитку економіки держави важливого значення набуває участь закладів освіти та наукових установ в економічній діяльності, зокрема в межах кластерів. Крім того, у чинному законодавстві, що стосується питань освіти, одним із принципів освітньої діяльності визначає державно-приватне партнерство, в межах якого на базі існуючих закладів освіти можуть утворюватися інноваційні центри, технопарки, технополіси, інноваційні бізнес-інкубатори, в межах яких буде здійснюватися інноваційна діяльність. Розроблена компетентнісна модель ураховує ці можливості.

Перспективним напрямом дослідження $\epsilon$ розробка факторно-критеріальних моделей для оцінювання рівня сформованості відповідних компетентностей на основі розробленої компетентнісної моделі у випускників закладів вищої освіти.

\section{СПИСОК ВИКОРИСТАНОЇ ЛІТЕРАТУРИ}

1. Архангельский С. И. Лекции по научной организации учебного процесса в высшей школе. Москва : Высшая школа, 1976. 200 с.

2. Волкова Н. П. Професійно-педагогічна комунікація: теорія, технологія, практика : монографія. Дніпропетровськ : Вид-во ДНУ, 2005. 304 с.
3. Гуцан Л. А. Компетентнісний підхід у сучасній освіті. URL: http://lib.iitta.gov.ua/2349/1/Gutsan 50025.pdf (дата звернення: 13.07.2020).

4. Державний стандарт України «Системи управління якістю вимоги» (ISO 9001:2001 IDT) . URL: https:// www.zoda.gov.ua/files/WP Article File/original/ 000011/11933.pdf (дата звернення: 13.077.2020).

5. Енциклопедія освіти / АПН України ; [гол. ред. В. Г. Кремень]. Київ : Юрінком Інтер, 2008. 1040 с.

6. Зікій Г. С. Формування фахової компетентності педагогів професійного навчання. URL: http://enpuir. npu.edu.ua/bitstream/123456789/19623/1/Zikiy.pdf (дата звернення: 30.06.2020).

7. Іваницький О. I. Формування інтегральної компетентності майбутнього вчителя фізики на засадах акмеологічного, контекстного та компетентнісного підходів. URL: http://journals.uran.ua/index.php/2307-4507/article/ download/125437/119890 (дата звернення: 29.06.2020).

8. КовальчукВ.А. Професійна компетентність вчителя в умовах варіативності освітньо-виховних систем. URL: http://irbis-nbuv.gov.ua/cgi-bin/irbis nbuv/ cgiirbis 64.exe?C21COM=2\&I21DBN=UJRN\&P21D $\mathrm{BN}=\mathrm{UJR} \overline{\mathrm{R}}$ \&IMAGE_FILE_DOWNLOAD $=1 \&$ Image file name $=$ PDF/Profos $201 \overline{6} \_10 \_22 . p d f$ (дата звернення: 30.06 .2020$)$.

9. Кравчук П. Ф. Формування розвинутої творчої особистості студента. Київ : Вища школа, 1984. 155 с.

10. Лещенко Г. А. Компетентнісна модель фахівця як системоутворюючий чинник його професійної підготовки. Наукові записки. Серія «Педагогічні науки». 2018. Вип. 173. С. 32-36.

11. Лунячек В. Е. Компетентнісний підхід як методологія професійної підготовки у вищій школі. URL: http:/www.kbuapa.kharkov.ua/e-book/putp/20131/doc/4/01.pdf_(дата звернення: 25.06.2020).

12. Лунячек В. Е., Рубан Н. П. Компетентнісна модель працівника закладу загальної середньої освіти у сфері інтелектуальної власності. Нова педагогічна думка. 2019. № 4 (100). С. 25-33.

13. Половенко Л. Управлінська компетентність ключовий складник професійної компетентності майбутніх фахівців економічного профілю. Гірська школа украӥнських Kарпат. 2015. № 12/13. С. 220-223.

14. Про затвердження Державного стандарту початкової освіти : постанова КМУ від 21.02.2018 № 87. URL: https://zakon.rada.gov.ua/laws/show/872018-\%D0\%BF\#Text (дата звернення: 25.06.2020).

15. Про затвердження Положення про центр професійного розвитку педагогічних працівників : проєкт постановиKMУ.URL:https://mon.gov.ua/ua/news/monproponuye-do-gromadskogo-obgovorennya-proyektpostanovi-kmu-pro-zatverdzhennya-polozhennya-procentr-profesijnogo-rozvitku-pedagogichnih-pracivnikiv (дата звернення: 30.06.2020).

16. Про освіту : Закон України від 05.09.2017 № 2145-VIII. Відомості Верховної Ради Украӥни. 2017. № 38/39. URL: https://zakon.rada.gov.ua/laws/ show/2145-19\#Text (дата звернення: 13.07.2020).

17. Про Рекомендації парламентських слухань «Захист прав інтелектуальної власності в Україні: проблеми законодавчого забезпечення та правозастосування» : постанова Верховної Ради України від 27 черв. 2007 р. № 1243-V. URL: https://zakon.rada.gov. ua/laws/show/1243-16 (дата звернення: 13.07.2020).

18. Сікора Я. Б. Формування професійної компетентності майбутнього вчителя інформатики засобами моделювання : автореф. дис. ... канд. пед. наук : 13.00.04. Житомир, 2010. 22 с. 
19. Часнікова О. В. Компетентнісний підхід в освіті як основа iii реформування. URL: https://www. narodnaosvita.kiev.ua/?page_id=2607 (дата звернення: 25.06.2020).

20. Шапран Ю. Педагогічне моделювання у процесі формування професійної компетентності майбутнього вчителя біології. Рідна школа. 2012. № 12. C. $39-43$.
21. Ягупов В. В., Свистун В. І. Компетентнісний підхід до підготовки фахівців у системі вищої освіти. URL: http://ekmair.ukma.edu.ua/bitstream/handle/123456 789/6871/Yagupov Svy\%60stun KOMPETENT NISNY\%60J PIDXID.pdf? sequence $=\overline{3}$ (дата звернення: $13.07 .20 \overline{20})$.

Дата надходження до редакиї: 30.07.2020 p.
УДК 37.013:001.895

DOI: 10.37026/2520-6427-2020-103-3-29-32

\section{Олександр ПАСТОВЕНСЬКИЙ,}

доктор педагогічних наук,

професор кафедри суспільно-гуманітарних дисииплін КЗ «Житомирський ОІППО»

Житомирської обласної ради,

заслужений прачівник освіти Украӥни

\section{СИСТЕМНИЙ ПІДХІД У РЕАЛІЗАЦІЇ ІДЕЙ ПЕДАГОГІКИ ПАРТНЕРСТВА}

У статті на основі системного підходу проаналізовано особливості реалізаиії ідей педагогіки партнерства в системі загальної середньої освіти. Зроблено висновок, шзо для ефективного впровадження ідей педагогіки партнерства необхідно забезпечити: різноманітність суб 'єктів партнерських взаємодій; розиирення сфери, де реалізуються зазначені взаємодї; урізноманітнення партнерських взаємодій в управлінні прочесами в закладах освіти; урахування рівня розвитку освітніх систем.

Ключові слова: системний підхід, педагогіка партнерства, освітня система, взаємодія, різноманітність, процес, управління, рівень розвитку.

В статье на основе системного подхода проанализированы особенности реализащии идей педагогики партнерства в системе общего среднего образования. Сделан вывод, что для эффективного внедрения идей педагогики партнерства необходимо обеспечить: разнообразие субъектов партнерских взаимодействий; расширение сферы, где реализуются указанные взаимодействия; разнообразие партнерских взаимодействий в управлении прочессами в учебных заведениях; учет уровня развития образовательных систем.

Ключевые слова: системный подход, педагогика партнерства, образовательная система, взаимодействие, разнообразие, прочесс, управление, уровень развития.

Implementation of the ideas of partnership pedagogy is one of the most important areas of modernization of the educational branch.

At the same time, the somewhat narrow interpretation of the pedagogy of partnership only as a cooperation of students, teachers and parents is one of the reasons for low efficiency of its implementation in practice.

The article proposes to expand the range of partners in interactions aimed at improving the educational process on the basis of a systems approach. Such partners may be the founder, the authorized body, the directorate of the educational institution, teachers, other employees of the institution, students, parents, self-governing bodies of the institution, the board of trustees, institutions of resource provision and support of educational and managerial activities, public associations educational process, etc.

It is emphasized that in the process of implementing the ideas of partnership pedagogy, one should take into consideration the fact that educational systems can have different levels of development - from a rigid system to a system with delegated management powers, a «soft» system, a network system and a synergy system.

The article also proposes to implement the ideas of partnership pedagogy in all major processes taking place in the educational system. The educational process, the development of the educational environment, the management process are among them.

In addition, it is emphasized that the pedagogy of partnership is important to be considered as a partnership of stakeholders at all stages of process management in the institution - from analysis and planning to organization, control and correction.

It is concluded that in order to successfully implement the ideas of partnership pedagogy in the system of general secondary education it is necessary to ensure: diversity of subjects of partnership interactions; expansion of the sphere where partnership ties are implemented; diversification of partnership relations in management processes in educational institutions; taking into consideration the levels of development of educational systems.

Key words: systems approach, partnership pedagogy, educational system, interaction, diversity, process, management, level of development.

Постановка проблеми. У статті 22 Закону України «Про повну загальну середню освіту» сформульована вимога до педагогічних працівників закладів загальної середньої освіти щодо дотримання принципів педагогіки партнерства у відносинах 3 учнями та їхніми батьками [6]. 